\title{
Existentialism of Engineering Marketing and Technological Entrepreneurship in Large Agricultural Enterprises
}

\author{
Tatiana Lyubanova ${ }^{1}$, Valery Lisitsin ${ }^{1 *}$, Lidia Shcherba $^{1}$, Yulia Oleynikova ${ }^{1}$ \\ ${ }^{1}$ Don State Technical University, Gagarina sq., 1, Rostov-on-Don, 344003, Russia
}

\begin{abstract}
The authors introduce their vision of modern world understanding by the managers and engineering staff of agricultural enterprises in the era of total communications and digitalization of agriculture, referring to the "seventh sense" as a fundamental instinct for comprehension of reality and existence which places human at the centre. In the technical age, engineering marketing is crucial in terms of perception of innovation technology advantages for development of a new entrepreneurial way of thinking, especially for engineers, given their significant participation in commercial projects of agro-industrial complex. The development of integrated hybrid production in agro-industrial complex for innovative agricultural production taking into account different business lines of various enterprises of the complex is suggested to achieve synergy and build a socially-oriented system. The proposals for business development are also introduced.
\end{abstract}

\section{Introduction}

In today's world, the information network is rapidly developing, integrating literally into all areas of society, which is assumed by the third wave of the Internet, meaning the "total internetization" of social life. In this regard, the principal intention of any country is not to get lost in a great number of competitors, but to correspond to the reality of the new era. There is no doubt that global changes are taking place in the world. Companies should not only observe them, but also participate in their perception and creation, bearing in mind that the future of digital economy is coming extremely quickly. In such conditions the existentialism of engineering

\footnotetext{
* Corresponding author: valis007@mail.ru
} 
marketing (EM) can help to create a generation of market-minded engineers with the use of such courses of study as: "Engineering Marketing", "Network Science", "Intelligent Technologies", "Engineering Software", "Communications in New Technological Paradigm", etc. with development of additional market competencies, taking into account the direction of Western European philosophy named existence which places a human being at the center of the study and states that intuition is the most important way of reality comprehension.

The issues of the existence of a certain economic entity, specifying different and constantly growing personnel requirements, are studied in the national scientific community inseparably with the problems of investment in human capital, processes of its development, including engineers and technicians, along with the role of human capital in science, technology and innovations, particularly in the agroindustrial complex (Guliyeva A., Chunikhina N., Guliyeva A., Abdulova A., Abuzyarova D., Belousova V., Krayushkina Zh., Lonshcikova Y., Nikiforova E., Chichkanov N., Litvintseva G., Nizovkina N., Gakhova N.) $[1,2,3]$.

The clusters' capacity of development of needed competencies and company flexibility, increase of enterprises' innovation efficiency, cooperation of business entities, of sectors of knowledge-intensive business services and also scientific and engineering areas of products and processes creation using marketing, the practical issues of development of science, technology and innovation are discussed in papers of numerous foreign authors (Calof J., Götz M., Inzelt A. Csonka I., Seidl da Fonseca R., Pinheiro-Veloso A., Pantazi X. E., Moshou D., Alexandridis T., Whetton R. L., Mouazen A. M., Navarro-Hellín H., Martínez-del-Rincon J., Domingo R., Soto F., Torres R., Ali M., Deo R. C., Downs N. J., Maraseni T.) [4, 5, $6,7,8,9,10]$.

A number of national researchers (Skvortsov E., Skvortsova E., Sandu I., Iovlev G., Anfinogentova A., Dudin M., Lyasnikov N., Protsenko O., Borisov A., Danilova S., Komarov V., Pronchenko L., Litvina N., Kuzmin V., Goryacheva A.) have considered the prospects of agro-industrial complex transition to the digital environment, application of artificial intelligence and training of highly qualified engineering personnel, taking into account the requirements of agribusiness companies, which, however, did not suggest the introduction of the specific marketing course into the educational process $[11,12,13,14,15,16]$.

The authors were inspired by the philosophical approach of Joshua Cooper Ramo [17] to understanding the world through the culture of a single country capable of changing the vision of the world to a large extent. Joshua Cooper Ramo studies this process on the example of China which in a remarkably short period of time managed to achieve the prosperity, largely due to the formed spirituality, meaning the Chinese "Chan Buddhism" which led to the creation of the Japanese school of "sudden enlightenment" about a thousand years ago.

It seems important to emphasize that it was the understanding of the world through spirituality that spread throughout China under the name of "Rinzai" and turned into the scientific direction (school), the mastermind and enlightener of which was the master Nan, who built the whole educational concept. Rinzai is based on the koans, known in the West and notable for their irrational, sometimes mathematical 
problems and solutions, but at the same time it is equally important to search for answers to emerging questions, which need to be answered more with the use of soul than of common sense, since the main message of this theory is "to adjust and succeed". In our opinion, for a Russian man such feeling as intuition, serendipity would be suitable when we have to resist logic and act as feelings suggest.

From our point of view, attention should also be paid to the fact that various ideas worth considering have appeared at all times in different sectors of the economy. For instance, more than 20 years ago the creative engineer John Deere came up with the idea of GPS navigation system for agricultural machinery which was the forerunner of entrepreneurial technology, i.e. self-driving transport equipment. Of course, back then, the implementation of such a breakthrough idea was not possible due to the lack of corresponding perception both of CEO (chief executive officers) and engineering personnel, as well as due to the difficulty of commercialization of this technology.

\section{Materials and methods}

The authors are confident that such courses as "Engineering Marketing" and "Network Science" with their methodology will help CEOs and market-minded engineers of large companies, including the agricultural machinery industry, to navigate the "seventh sense" as a new way of thinking.

As is known, the "sixth sense" was defined by Nietzsche at the beginning of the 20th century as an instinct helping people to survive the industrial revolution. In light of the onset of the third wave of Internet, due to the research works of Steve Jobs, Steve Case, Joshua Cooper Ramo and other scientists [18, 19, 20, 21] the inner understanding of modern world and digital revolution significance came, including the "seventh sense" as a premonition of the era of total communications, where communication is accelerating at a greater speed. According to many scholars, communications change the properties of an object.

It should be noted that if the simple objects and devices became complex due to the sixth sense (for example, agriculture became mechanized replacing the farmer's work), then the seventh sense can turn complex objects and devices into comprehensive systems. It should be emphasized, that comprehensive systems change the "rules of the game", creating amazing interaction and, sometimes, unpredictability. It is interesting that the complex systems themselves are complex mechanisms which help to develop smart autonomous agricultural machinery, using global, collective intelligence. For example, the company OOO KZ "Rostselmash" is currently bringing its self-driving combine harvester onto the market. The introduction of such machines in large agro-industrial complexes will undoubtedly lead to the increase of farm productivity, significantly changing the profession of a farm machine operator. The enterprises of the agro-industrial complex themselves are already turning into stable and self-improving complex systems.

It should also be borne in mind that many new ideas appear in different industries. As to the Russian industry, the authors note that in the annual rating of 
500 largest companies of Russia [22] for the first time there was presented the integrated sector "defense industrial complex and mechanical engineering" among the new industries. According to the authors, the introduction of such sector is the right decision in the context of transition to the sixth and seventh technological paradigms and to the fifth industrial revolution. This decision will help: firstly, to increase the diversification of the defense industrial complex (DIC) including competitive civilian products; secondly, to form a government order for the entire industry for the production of brand-new innovation equipment; thirdly, to upgrade the material and technical basis of all industries; and, finally, to improve the quality of civilian products, using high technical and technological capacity of the defense industrial complex.

The authors also note the importance of other new industries shown in the rating for efficient industrialization of the country. Such new sectors as "Nuclear Industry", "Information Technologies", "Telecommunications", "Media and Internet", "Investments" and others are attractive, because they can significantly accelerate the development of engineering marketing towards engineering software and technological entrepreneurship development for rapid increase of Russian industrialization efficiency, bearing in mind that Russia is an engineering country.

The analysis of the rating of 500 large companies of Russia showed that in the current period Russian large business has a downward trend, despite a slight increase of GDP by $1.3 \%$ and inflation of $3.4 \%$. Compared to the previous rating, the revenues of such giants as Gazprom, Rosneft and Lukoil has reduced and in the coming years it is not expected to grow as in the past. In this respect it is really difficult to expect growth of large companies as a whole. Although world-known information companies, including Yandex, Mail.ru., Wildberries, are developing aggressively and rapidly, they cannot be compared with the mentioned giants. It should be noted that although metallurgy, oil and gas, chemical sectors have slowed down sharply, at the same time, their share of total revenue in the overall rating of large companies is still rather high and amounts to $41.5 \%$ (43.5\% in the previous rating).

Large agricultural companies increased by an average of $12 \%$, food companies by $10 \%$. The consumer sectors are also growing, and the most important reasons for this situation can include: the low cost of Russian rouble, stimulating import substitution, the expansion of the range of producers, export growth of many types of agricultural commodities. In addition, a positive attitude to consumer loans, which grew by an average of $15-20 \%$, stimulates the development of domestic economy, and the ongoing easing of monetary policy (reduction of rates for both businesses and people) also leads to the growth of the consumer market.

Based on the rating of 50 largest companies of the Russian agro-industrial complex according to the results of 2019 [23], the authors show their interpretation of the rating in Table 1, expanding its original version with the necessary data for completeness and visibility of analysis, adding one more column (20 fastest-growing companies of agro-industrial complex (rating)) to analyze changes of both revenue growth and growth rates increase with the use of one table. The enterprises included in the rating of 50 largest companies of the Russian agro-industrial complex 
according to the results of 2019 were ranked in terms of their revenue change, and twenty of them with the highest rates of change were rated from 1 to 20 . In Table 1 the information about these companies was highlighted in bold. In the cells of column 6 relating to enterprises that are not included in the rating of 20, dashes are put down. The performed double ranking allows for the consideration of activities of 50 leading agro-industrial enterprises of the Russian Federation not only within the framework of change of the absolute indicator of revenue, but also according to the relative indicator of change in its growth rate, which gives a better overall picture of the situation in the industry.

Table 1. The rating of 50 largest companies of the Russian agro-industrial complex according to the results of 2019 (the interpretation of the authors).

\begin{tabular}{|c|c|c|c|c|c|}
\hline $\begin{array}{c}\text { Place } \\
\text { in the } \\
\text { rating } \\
\text { in } \\
2019 \\
(2018)\end{array}$ & Company name & Specialization & $\begin{array}{l}\text { Revenue } \\
\text { in } 2019 \\
\text { (million } \\
\text { roubles) }\end{array}$ & $\begin{array}{c}\text { Change } \\
(\%)\end{array}$ & \begin{tabular}{|}
20 fastest- \\
growing \\
companies \\
of agro- \\
industrial \\
complex \\
(rating)
\end{tabular} \\
\hline 1 & 2 & 3 & 4 & 5 & 6 \\
\hline 1 & $\begin{array}{c}\text { Group of companies } \\
\text { "Sodrurzestvo" } \\
\text { ("S-Soya", "Agroprodukt" + } \\
\text { TDS) }\end{array}$ & Oilseed processing & 202000 & 15.6 & 17 \\
\hline 2 & $\begin{array}{l}\text { Group of companies } \\
\text { "Rusagro" }\end{array}$ & $\begin{array}{l}\text { production of sugar, pork, fat } \\
\text { and oil products, crop growing }\end{array}$ & 138172 & 66.5 & 3 \\
\hline 3 & $\begin{array}{l}\text { Group of companies } \\
\text { "Ephko" }\end{array}$ & $\begin{array}{l}\text { production of refined vegetable } \\
\text { oils and fats }\end{array}$ & 122000 & 7.0 & - \\
\hline 1 & 2 & 3 & 4 & 5 & 6 \\
\hline 4 & $\begin{array}{l}\text { Group of companies } \\
\text { "Cherkizowo" }\end{array}$ & $\begin{array}{l}\text { breeding of pigs and poultry, } \\
\text { processing, production of meat } \\
\text { products and animal feed }\end{array}$ & 120109 & 17.0 & 16 \\
\hline 5 & Agroholding "Miratorg" & $\begin{array}{l}\text { livestock and crop production, } \\
\text { processing }\end{array}$ & 119150 & 6.8 & - \\
\hline 6 & $\begin{array}{l}\text { Group of companies } \\
\text { "Danon" } \\
\text { (OOO "Danon Trade") }\end{array}$ & food industry & 109478 & -1.6 & - \\
\hline 7 & $\mathrm{AO} \mathrm{VBD}$ & production of beverages and food & 100298 & 2.0 & - \\
\hline 8 & $\begin{array}{l}\text { OOO "Kargill", OOO } \\
\text { "Provimi" }\end{array}$ & $\begin{array}{l}\text { production of starch and starch } \\
\text { products, production of sugar and } \\
\text { sugar syrups, animal feed }\end{array}$ & 81248 & -0.6 & - \\
\hline 9 & $\begin{array}{l}\text { Group of companies } \\
\text { "Agro-Belogorie"1 }\end{array}$ & $\begin{array}{l}\text { livestock husbandry and crop } \\
\text { production }\end{array}$ & 78650 & 2.4 & - \\
\hline 10 & $\begin{array}{c}\text { AO "Aston produkty pitania i } \\
\text { pishevyie ingredienty" } \\
\text { (AO "Aston") }\end{array}$ & $\begin{array}{l}\text { production of food and food } \\
\text { ingredients }\end{array}$ & 66784 & -18.2 & - \\
\hline
\end{tabular}




\begin{tabular}{|c|c|c|c|c|c|}
\hline 11 & $\begin{array}{l}\text { Group of agricultural } \\
\text { companies "Resurs" }\end{array}$ & $\begin{array}{c}\text { production of food from poultry } \\
\text { meat, growing grains and } \\
\text { oilseeds }\end{array}$ & 61232 & 15.2 & 18 \\
\hline 12 & "Norebo Holding"1 & catch of fish and seafood & 60500 & 4.3 & - \\
\hline 13 & $\begin{array}{l}\text { Group of companies } \\
\text { "Agropromkomplektatsiya"1 }\end{array}$ & $\begin{array}{l}\text { crop production, livestock } \\
\text { husbandry, feed production }\end{array}$ & 58947 & 3.0 & - \\
\hline 14 & $\begin{array}{c}\text { Velikolukskiy } \\
\text { agropromyshlenniy holding }^{1}\end{array}$ & $\begin{array}{c}\text { breeding of pedigree pigs, meat } \\
\text { processing }\end{array}$ & 57600 & 19.0 & 11 \\
\hline 15 & $\begin{array}{c}\text { Firma "Agrokompleks im. N.I. } \\
\text { Tkacheva" }\end{array}$ & $\begin{array}{l}\text { crop production and livestock } \\
\text { husbandry (mixed farming) }\end{array}$ & 53200 & 6.3 & - \\
\hline 16 & $\begin{array}{c}\text { Agroholding "BEZRK-Belgran- } \\
\text { korm"1 }\end{array}$ & $\begin{array}{c}\text { livestock husbandry and crop } \\
\text { production, production of poultry, } \\
\text { pork, beef and sausage products }\end{array}$ & 50200 & 4.4 & - \\
\hline 17 & $\begin{array}{c}\text { Agroholding "Komos } \\
\text { Grupp" }\end{array}$ & $\begin{array}{c}\text { pig breeding, poultry breeding, } \\
\text { meat and milk processing, } \\
\text { animal feed production }\end{array}$ & 49700 & 17.8 & 13 \\
\hline 18 & OOO "Prodimeks" & sugar production & 45120 & 21.1 & 9 \\
\hline 19 & $\begin{array}{c}\text { OAO "Ostankinskiy } \\
\text { myasopererabatyvayushiy } \\
\text { kombinat" }\end{array}$ & $\begin{array}{c}\text { pig breeding, production of } \\
\text { processed meat and semi-finished } \\
\text { products }\end{array}$ & 41761 & 1.1 & - \\
\hline 20 & ZAO "Prioskolie" & poultry farming & 38746 & 10.4 & - \\
\hline 21 & Agro-industrial group "Prodo" & $\begin{array}{c}\text { poultry breeding, pig breeding and } \\
\text { meat processing }\end{array}$ & 38000 & 2.7 & - \\
\hline 1 & 2 & 3 & 4 & 5 & 6 \\
\hline 22 & AO NMRZK & production of margarine and food & 35306 & 8.8 & - \\
\hline 23 & AO "Agrosila"1 & $\begin{array}{c}\text { growing of grains, industrial and } \\
\text { fodder crops, production of animal } \\
\text { feed and oils, livestock production, } \\
\text { poultry farming, procurement and } \\
\text { industrial processing of grain for } \\
\text { production of flour and cereals, } \\
\text { processing of sugar beet, } \\
\text { production of milk and dairy } \\
\text { products }\end{array}$ & 33130 & -12.8 & - \\
\hline 24 & "KoPitania" & $\begin{array}{c}\text { full cycle agro-industrial holding, } \\
\text { from crop production to } \\
\text { production and sale of meat } \\
\text { products } \\
\end{array}$ & 31433 & -2.7 & - \\
\hline 25 & $\begin{array}{c}\text { Agroholding "Step" } \\
\text { (agrobusiness AFK } \\
\text { "Sistema") }\end{array}$ & $\begin{array}{c}\text { crop production, dairy } \\
\text { husbandry, intensive gardening, } \\
\text { vegetable farming and } \\
\text { agricultural products trading } \\
\end{array}$ & 31044 & 28.5 & 5 \\
\hline 26 & OOO MEZ "Yug Rusi" & $\begin{array}{l}\text { production of crude vegetable } \\
\text { oils }\end{array}$ & 29983 & 22.3 & 8 \\
\hline 27 & $\begin{array}{l}\text { Group of agricultural } \\
\text { companies "Damate" }\end{array}$ & $\begin{array}{l}\text { agricultural production (turkey } \\
\text { farming and processing, } \\
\text { milkproduction and processing) } \\
\end{array}$ & 26300 & 40.6 & 4 \\
\hline 28 & $\begin{array}{l}\text { “Russkaya rybnaya } \\
\text { kompaniya" (RPPK) }\end{array}$ & $\begin{array}{l}\text { catch and sale of fish and } \\
\text { seafood }\end{array}$ & 24984 & 17.5 & 14 \\
\hline
\end{tabular}




\begin{tabular}{|c|c|c|c|c|c|}
\hline 29 & MPK “Atyashevskiy”1 & $\begin{array}{c}\text { production of sausage products } \\
\text { and meat delicacies }\end{array}$ & 24814 & 10.7 & - \\
\hline 30 & Sibirskaya Agrarnaya Gruppa ${ }^{1}$ & $\begin{array}{l}\text { agriculture, pig husbandry, food } \\
\text { production }\end{array}$ & 24715 & 5.3 & - \\
\hline 31 & "EkoNiva - APK Holding""1 & livestock and crop production & 24557 & 70.4 & 2 \\
\hline 32 & OOO "Kompaniya "Blago" & production of vegetable oils & 23398 & 14.2 & 19 \\
\hline 33 & $\begin{array}{c}\text { Group of companies } \\
\text { AST }\end{array}$ & $\begin{array}{c}\text { grain production, storage, } \\
\text { processing }\end{array}$ & 22575 & 85.1 & 1 \\
\hline 34 & Group "Sphera"1 & $\begin{array}{l}\text { production and processing of } \\
\text { agricultural products }\end{array}$ & 21646 & -5.4 & - \\
\hline 35 & AO "Molvest" & dairy production & 21154 & 13.9 & 20 \\
\hline 36 & $\begin{array}{c}\text { AVK "Eksima" (the core asset } \\
\text { is Mikoyanovskiy meat- } \\
\text { processing plant) }{ }^{1}\end{array}$ & meat processing and canning & 20759 & -3.4 & - \\
\hline 1 & 2 & 3 & 4 & 5 & 6 \\
\hline 37 & Holding "Avangard-Agro" & agricultural production & 20684 & 19.4 & 10 \\
\hline 38 & Group of companies "Renna" & $\begin{array}{l}\text { production of canned milk, whole- } \\
\text { milk products and ice cream }\end{array}$ & 20668 & -7.5 & - \\
\hline 39 & Ptitsefabrika "Severnaya" & poultry breeding & 20664 & 3.1 & - \\
\hline 40 & $\begin{array}{l}\text { OOO "Ptitsefabrika } \\
\text { "Akashevskaya" }\end{array}$ & poultry breeding and processing & 20274 & 25.3 & 6 \\
\hline 41 & $\begin{array}{c}\text { "Aladushkin grupp" } \\
\text { (the core asset is grain } \\
\text { processing plant Leningradskiy } \\
\text { kombinat chleboproduktov } \\
\text { imeni S.M. Kirova) }{ }^{1}\end{array}$ & \begin{tabular}{|} 
production of flour from grain and \\
vegetable crops, production of \\
ready-made flour mixes and dough \\
for baking, cereals, pellets and \\
other products from grain crops, \\
production of ready-made feed
\end{tabular} & 18722 & 3.6 & - \\
\hline 42 & Agroholding "Trio"" & $\begin{array}{l}\text { sugar production, dairy husbandry, } \\
\text { crop production }\end{array}$ & 18480 & 8.1 & - \\
\hline 43 & “Okeanrybflot" & catch of fish and seafood & 18313 & 18.2 & 12 \\
\hline 44 & AO "Makpha" & $\begin{array}{c}\text { production of flour from grain } \\
\text { and vegetable crops, production } \\
\text { of ready-made flour mixes and } \\
\text { dough for baking }\end{array}$ & 17861 & 17.3 & 15 \\
\hline 45 & $\begin{array}{l}\text { Group of companies } \\
\text { "Dominant" } 1\end{array}$ & $\begin{array}{l}\text { sugar production, dairy and meat } \\
\text { processing plants }\end{array}$ & 17716 & 9.6 & - \\
\hline 46 & $\begin{array}{l}\text { Group of companies "Yanta" } \\
\text { (the core assets include } \\
\text { Irkutskiy MRZK and } \\
\text { Angarskaya ptitsefabrika) }{ }^{1}\end{array}$ & $\begin{array}{l}\text { production of high-quality food } \\
\text { products, raw materials for food } \\
\text { and processing industry, } \\
\text { agricultural feed }\end{array}$ & 17401 & -5.9 & - \\
\hline 47 & $\begin{array}{l}\text { PAO "Russkaya } \\
\text { akvakultura"' }\end{array}$ & $\begin{array}{l}\text { growing, processing and canning } \\
\text { of fish, crustaceans and molluscs }\end{array}$ & 16207 & 22.7 & 7 \\
\hline
\end{tabular}




\begin{tabular}{|c|c|c|c|c|c|}
\hline 48 & $\begin{array}{c}\text { Group of companies } \\
\text { "APK Don" }\end{array}$ & $\begin{array}{c}\text { livestock, crop production, fodder } \\
\text { production }\end{array}$ & 15989 & -0.6 & - \\
\hline 49 & $\begin{array}{c}\text { Group of companies } \\
\text { "Zdorovaya pherma"1 }\end{array}$ & livestock, food production & 14990 & - & - \\
\hline 50 & Agroholding "Zvenigovskiy" & $\begin{array}{c}\text { livestock, crop production, } \\
\text { processing }\end{array}$ & 14934 & 3.6 & - \\
\hline \multicolumn{2}{|r|}{ Total revenue } & 2341596 (million roubles) \\
\hline
\end{tabular}

${ }^{1}$ The revenue was calculated based on transactional data of companies

The analysis shows that the total revenue of the largest Russian agro-industrial companies according to the results of 2019 increased by $11.4 \%$ compared to 2018 and amounted to 2.34 trillion roubles. It should be noted that agro-industrial enterprises have shown double-digit revenue growth not for the first time, regardless of volatile yield, market conditions, increased competition and other factors. This is largely due to the consolidation of agro-industrial companies for increase of their revenue, since the revenue of minimum 149 billion roubles had to be reached for getting into the rating. Furthermore, three new companies were included in the rating: AST Group of companies - 33rd place in the rating; "Trio" agroholding 42nd place; "Dominant" Group of companies - 45th place, as well as three fishing companies - "Norebo Holding", "Russkaya rybnaya kompaniya" (the trading company of RPPK holding) and "Okeanrybflot", which took respectively 12th, 28th and 43rd places in the rating of 50 large companies of the Russian agro-industrial complex. In addition, it seems interesting that counter-sanctions were introduced by Europe for Russian suppliers of agricultural products in 2014. For the period from 2014 to 2019 the revenues of 50 agro-industrial companies amounted to 948 billion roubles, the cumulative inflation for this period reached $45 \%$. This fact underlines that Russian agro-industrial companies actually increased their revenue on the background of economy stagnation. Analyzing Table 1, it is worth noting that Russian agro-industrial complex is characterized by uneven development. In this regard seven large holdings with the revenue of more than 100 billion roubles can be distinguished, which hardly compete with each other and hold leading positions in different areas of agriculture, that is, they differentiate their activities. Table 1 shows that the leader in the rating in terms of revenue is the export-oriented "Sodrurzestvo" Group of companies, the largest producer of vegetable oils in Russia. Besides, the company is engaged in the processing of soybeans and rapeseed, procurement of grain and oil crops. In 2019, company's revenue amounted to 202000 million roubles, showing the increase of $15.6 \%$ in comparison to the previous rating. In second place is the "Rusagro" Group of companies, producer of sugar, pork, fat-and-oil products, engaged in crop-growing. The revenue of this enterprise amounted to 138172 million roubles. The specific feature of the company's business growth includes various types of transactions and acquisitions with the use of borrowed funds. For instance, the "Rusagro" Group of companies acquired a large share of the "Agro-Belogorie" Group of companies, last year it bought the assets of "Solnechnye Produkty" company, and earlier, in 2015, it 
acquired the assets of "Razgulyai" company" by purchasing its debt. The third place in the given rating is taken by the "Ephko" Group of companies, the largest enterprise of fat-and-oil products in Russia. Its revenue amounted to 122000 million roubles with the increase of $7 \%$ compared to the previous period. The activity of this company is focused mainly on the domestic market. Four more companies included in the top seven divided their spheres of influence according to the specialization areas indicated in Table 1 . The total revenue of these seven companies amounted to 911207 million roubles and about $40 \%$ of the total revenue of 50 agro-industrial companies included in the rating. It can be noted that all the leaders are high-cost enterprises with capital-intensive production, since they produce higher value added products. For example, it could be a processing plant with related infrastructure including treatment facilities, roads, electricity grids. It is clear that the scale makes it possible for large leading companies to obtain necessary resources for new construction and development.

The fastest-growing companies of agro-industrial complex in terms of rising growth rates include 20 enterprises presented in the rating in column 6 of Table 1 . The first place in the rating is taken by the AST Group of companies, which is one of the leading agro-industrial holdings of the Russian Federation. This diversified holding is engaged in grain production, storage, processing, as well as in wholesale trade of grain and grain products. The second place in the rating belongs to "EkoNiva - APK Holding", the largest milk producer in Russia and the sixth in the world. The company ranks seventh in the world in terms of livestock population [23]. It is worth noting that growth of "EkoNiva" is organic, because the company prefers to develop its own projects instead of acquiring the new ones. The third place in terms of rising growth rates, but not in terms of revenue, is taken by the "Rusagro" Group of companies, the financial leader of the rating of agro-industrial companies, as evidenced by its highest revenue. The average growth rate of 20 fastest-growing agro-industrial companies amounted to $28.38 \%$, while the AST Group of companies shows growth of $85.1 \%$, and the outsider AO "Molvest" shows only $13.9 \%$, which indicates the uneven development. The total revenue of 20 fastest-growing companies amounted to 971267 million roubles and seems to be significant in the total revenue of 50 large agro-industrial companies, amounting to $41.47 \%$, which indicates the importance and rather high development of large agricultural enterprises.

The authors note, that in recent years the agricultural sector provided necessary products not only for the domestic market, but also for the countries of near and far abroad. The supplies of Russian agricultural products abroad have already exceeded the income from export of military-industrial complex products, almost completely replacing import of some of its kinds with domestic production. Government support for Russian agro-industrial companies and food industry is quite significant. This is supported by nationwide projects in 12 areas of work until 2024 , including the priority project "The export of agricultural products" which is dedicated to removal of barriers to export and opening of new markets. The Center "Agroeksport" for the analysis of agricultural production was established. The purpose of the project is to increase supplies of agricultural products to foreign 
markets, bringing them to 45 billion roubles by the end of 2024. Over the past 10 years, Russian export of agricultural products has grown 19 times. Subsidies are offered for contracting with investors, soft loans are granted for organization of block train shipments of agricultural and food products, for implementation of about 100 corporate programs of international competitiveness (KPMK) by 2021. Unfortunately, public funding leaves much to be desired, given that agricultural production in foreign countries is publicly subsidized. There are interesting strategic projects in the regions, for example, the noteworthy 10-year project of the Tomsk company "Sava", which is called "Severnyiy sad" ("Northern Garden"). The project includes creation of the largest honeysuckle garden in the country. The company invests 300 million roubles in this project. It is promised that this rare, good for health, Russian berry will be available to the mass-market customer in three years [24].

The "Sava" company has been specialized in processing of wild crops in Siberia and Altai territory for 20 years, and for several years - in cultivation of sea buckthorn gardens. According to experts, with whom the authors agree, the strategic development of horticulture and the establishment of gardens is the right decision, that is why the agricultural project "Severnyiy sad" was added to the company's assets. Furthermore, the breeding center "Bakcharskoye", known worldwide for its varieties of blue honeysuckle, was also involved. It should not be ignored that Europe is interested in this good for health and new in the market berry, which was included in the EU food list and, as a result of successful commercial project, it is grown in Holland on the basis of honeysuckle varieties exported from the Russian breeding center "Bakcharskoye". Why is the Dutch project highly profitable? Because technological entrepreneurship is traced at all stages of engineering activity, including intensive technologies for growing berries, yielding up to five tons per hectare, and harvesters with mechanized harvesting, which provides up to $95 \%$ of the harvest (while manual harvesting loses half of the crop), drip irrigation, which is also an engineering effort, etc. In this aspect, given the significant engineering component of commercial start-up, the Russian project team can use competencies, the development of which is provided by the "Engineering Marketing" course, as well as the existentialism of engineering marketing and technological entrepreneurship in large agricultural enterprises.

\section{Results}

Currently, the digital economy in agriculture also becomes very important. The project sponsor is the bank AO "Rosselkhozbank", which, in our opinion, is a true partner of agro-industrial complex, helping to accomplish a radical restructuring to improve work efficiency. Unfortunately, according to experts, only 5\% of domestic large agricultural companies use digital technologies, including the "Rusagro" Group of companies, AO "Belaya Dacha" and others. It is known that the development of corresponding digital platforms and services, engineering software is quite expensive. The obsolete management system of many agricultural 
enterprises cannot accept this, largely due to the lack of the necessary specialists. The scheme for managing digital transformation and implementation of artificial intelligence (AI) (Figure 1) is proposed in the paper of Nick Spirin, CEO of "Neuroinfra" company and the author of the course for executives "Business Transformation: Implementing Artificial Intelligence "Netology" [25].

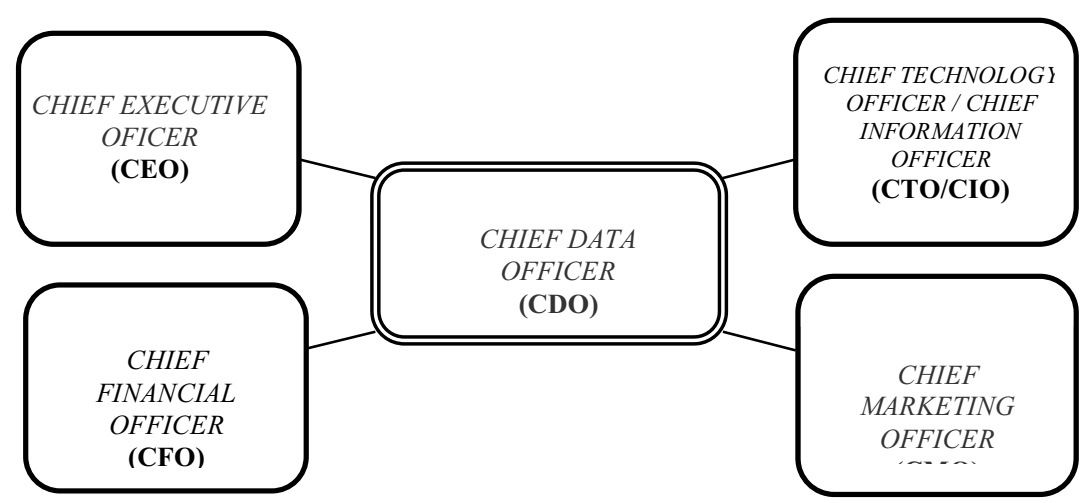

Fig. 1. The scheme of managing digital transformation and AI implementation.

It seems that this scheme for large agricultural companies can be represented in our interpretation of marketing management of digital transformation (Figure 2). Digital transformation means a new approach to the agro-industrial complex management project in terms of digital economy in contrast to typical projects of local upgrade.

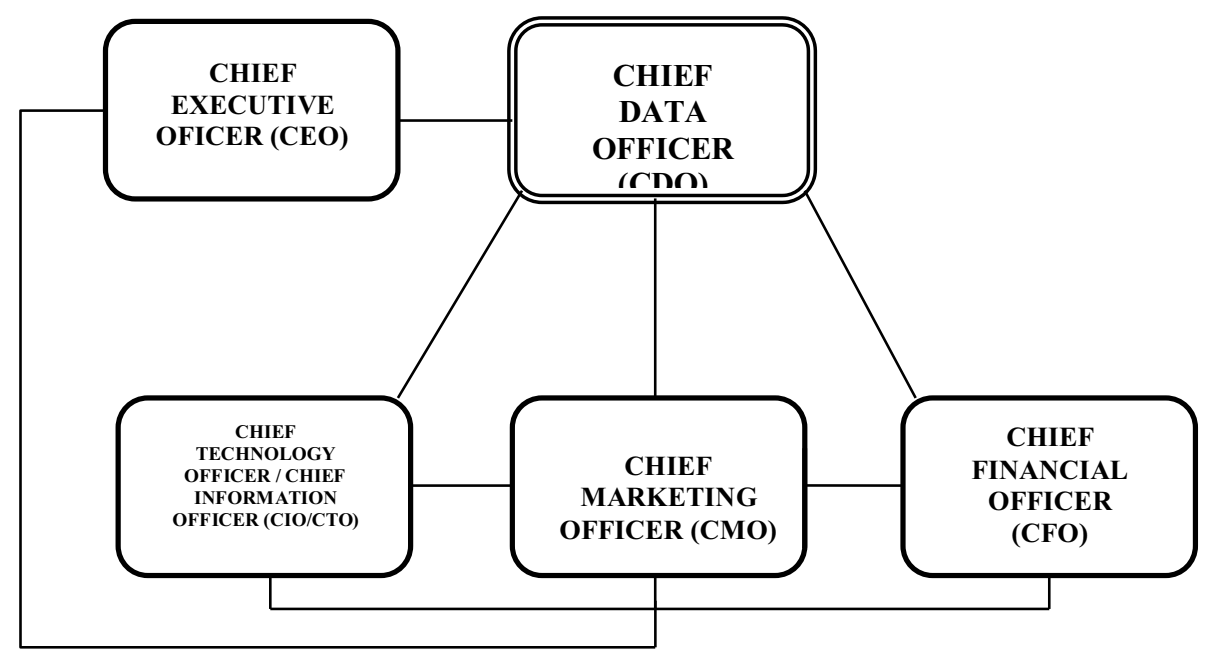

Fig. 2. The scheme of managing digital transformation in agro-industrial complex (the interpretation of the authors). 
This scheme shows the importance of chief specialists in marketing management under the conditions of digital economy, emphasizing the respective roles of both the Chief Data Officer (CDO) who ensures digitalization, and the Chief Marketing Officer (CMO) who coordinates the role of agricultural marketing. In order to implement this significant work, interdisciplinary teams should be created in each agricultural company, which should include agricultural specialists, marketers, programmers, analysts, scientists, engineers with additional market competencies, mathematicians and other specialists. It is very important to find a creative leader who understands the new era of technology and knows how to organize team work in an integrated manner.

\section{Discussion}

To ensure national technological parity, a radically different approach is needed, most of all, to management of science in all areas of creation and production of products based on the intellectualization of research work both on the national scale and at the level of agricultural enterprises, specifically companies of agro-industrial complex. In this case, in our opinion, engineering marketing can be used for technological entrepreneurship development at all stages of engineering activity. In the authors' view, as mentioned in many of their publications, engineering marketing suggests marketing orientation of engineering activity, including the whole engineering work as a basis of technological entrepreneurship, taking into account market conditions of management, starting with the creation of products based on engineering solutions and ending with product distribution, finding appropriate transportation solutions and working with the consumer. At the same time, technological entrepreneurship is understood both as the most important business component of agro-industrial complex, and as a way to create a marketminded generation of engineers with respective market competencies and entrepreneurial skills.

In our opinion, in the context of Russian globalization, particularly for corporate entities typical for agro-industrial complex, it is useful to develop an "integrated hybrid agricultural production", which includes integration processes of creating innovation agricultural products in certain areas by various enterprises included in the complex, based on efficient management of value chains from the perspective of existentialism of engineering marketing and technological entrepreneurship in large agricultural enterprises. The value chain involves optimization of engineering activities and costs through their distribution between a large number of agricultural enterprises working in different areas, which creates synergy by conjoining the good things of all companies. At the same time, the value chain is considered as a pyramid based on the technical competence, genetic technology, innovative materials, etc., which eventually provide the development of hybrid production in agro-industrial complex.

Considering the above, the authors have come to the conclusion that agroindustrial companies need engineering personnel with systems thinking, high skill 
level, focused on multidisciplinary training with additional market competencies for proper solution of technical and business problems based on engineering marketing in agricultural production and creation of socially-oriented technological system. From that standpoint the authors highlight the essential paradigm of marketing evolution, namely, the existentialism of engineering marketing of agricultural complex as its market concept, the purpose of which is to "renew and update" in the context of changing market. Engineering marketing is responsive to everything new and can adapt during its evolutionary development, which is confirmed by the tools previously developed by the authors in the form of marketing model of various engineering solutions, engineering marketing mix (EMM) as an EMM formula, business model of engineering marketing and the process of its implementation with the use of psychoheuristic programming methods, information technologies, different IoT platforms (for example, "Data telemetering"), M2M tools (machine-tomachine interaction), and engineering software [26].

\section{Conclusions}

Thus, it can be stated that the "Agriculture and food production" sector, which is important for development of socially-oriented technological system in Russia, is increasing its production. In order to ensure national technological parity, the authors suggest a new approach in the form of engineering marketing existentialism for technological entrepreneurship development in agro-industrial companies along with training of creative engineering personnel with additional market competencies. Technological entrepreneurship involves automation and robotization at all stages of agricultural production and delivery of products to the consumer, starting with the research and development, production, including sowing, planting, irrigation, using gene growing technologies, harvesting with the use of appropriate transport equipment and other innovative engineering solutions. The analysis of the rating of 50 large agro-industrial companies is carried out in the paper, their advantages and disadvantages are highlighted. The large agricultural enterprises, which are not included in the rating, are considered. The suggestions for development of technological component and business prospects of considered agro-industrial enterprises are given. The issues of digital economy in the development of agroindustrial complex are touched upon and the scheme for managing digital transformation of agro-industrial companies is suggested.

\section{Referencies}

1. A. Guliyeva, N. Chunikhina, A. Guliyeva, A. Abdulova, Terra Economicus, 17(1), 64-76 (2019)

2. D. Abuzyarova, V. Belousova, Zh. Krayushkina, Y. Lonshcikova, E. Nikiforova, N. Chichkanov, Foresight and STI Governance, 13(2), 107-119 (2019) 
3. G. Litvintseva, A. Nizovkina, N. Gakhova, The Education and science journal, 19(2), 101-123 (2017)

4. J. Calof, Foresight and STI Governance, 12(3), 30-33 (2018)

5. M. Götz, Foresight and STI Governance, 13(2), 72-83 (2019)

6. A. Inzelt, I. Csonka, Foresight and STI Governance, 11(4), 63-73 (2017)

7. R. Seidl da Fonseca, A. Pinheiro-Veloso, Foresight and STI Governance, 12(2), 6-22 (2018).

8. X.E. Pantazi, D. Moshou, T. Alexandridis, R.L. Whetton, A.M. Mouazen, Computers and Electronics in Agriculture, 121, 57-65 (2016)

9. H. Navarro-Hellín, J. Martínez-del-Rincon, R. Domingo, F. Soto, R. Torres, Computers and Electronics in Agriculture, 124, 121-131 (2016)

10. M. Ali, R.C. Deo, N.J. Downs, T. Maraseni, Computers and Electronics in Agriculture, 152, 149-165 (2018)

11. E. Skvortsov, Ekonomika regiona [Economy of Region], 16(2), 563-576 (2020)

12. E. Skvortsov, E. Skvortsova, I. Sandu, G. Iovlev, Ekonomika regiona [Economy of Region], 14(3), 1014-1028 (2018)

13. A. Anfinogentova, M. Dudin, N. Lyasnikov, O. Protsenko, Economika regiona [Economy of Region], 14(2), 638-650 (2018)

14. A. Borisov, S. Danilova, IOP Conference Series Earth and Environmental Science, 548 (2020)

15. V. Komarov, L. Pronchenko, N. Litvina, Alma mater. Vestnik Vysshey Shkoly, 3, 70-74 (2020)

16. V. Kuzmin, A. Goryacheva, Vestnik of Moscow Goryachkin State Agroengineering University, 5(87), 51-56 (2018)

17. J.C. Ramo, New York: Little, Brown \& Company, 352 (2016)

18. S. Case, New York: Simon \& Schuster, 272 (2017)

19. S. J. Spear, New York: McGraw-Hill, 432 (2008)

20. S. Ellis, M. Brown, London: Ebury-Publishing, 320 (2017)

21. P. Marsh, New Haven: Yale University Press, 320 (2013)

22. Rating of 500 largest companies of Russia 2018, Expert Journal, 10(144) (2018)

23. Special Report: Rating of 50 Largest Companies of the Russian Agro-industrial Complex (according to the results of 2019), Expert Journal, 47, available at: http://www.acexpert.ru/ (accessed 15.01.2021) (2020)

24. V. Bezuglova, Expert Journal, 43, available at: https://expert.ru/ (accessed 11.01.2021) (2020)

25. N. Spirin, Expert Journal, 43, available at: https://expert.ru/ (accessed 14.01.2021) (2020)

26. T. Lubanova, D. Zozulya, Saarbrücken: LAP LAMBERT, 176 (2012) 